\title{
MANFAAT MASASE WAJAH DAN VITAMIN E PADA ATLET
}

Oleh : Ali Satya Graha

Dosen Jurusan Pendidikan Kesehatan dan Rekreasi FIK UNY

Abstrak

Masase pada era modern memegang peranan penting dalam mendukung prestasi atlet yang tergabung dalam rehabilitasi medik bersama medis, fisioterapi dan psikolog. Tetapi masase juga banyak sekali diminati oleh atlet wanita maupun laki-laki sebagai salah satu perawatan untuk kecantikan dan ketampanan fisik sebagai pancaran kecantikan dan ketampanan yang ada dalam dirinya. Masase yang terkenal untuk merawat kecantikan menggunakan masase Swedia dan masase Baeuty atau masase cosmetic. Wanita perlu perawatan khusus dalam memasase wajah dan tubuh dengan sentuhan pijitan yang lembut seperti pada penatalaksaaan masase Swedia dan masase Beauty. Masase wajah sangat bermanfaat untuk merawat dan mencegah penuaan wajah baik kulit maupun otot wajah agar selalu tetap sehat dan bugar.

Vitamin E merupakan antioksidan (pencegah oksidasi) biologis yang berdiri sebagai benteng pertahanan pertama melawan peroksida lipid yang menghasilkan radikal bebas penyebab kerusakan jaringan. Penggabungan perawatan dengan masase wajah dan pemberian vitamin $\mathrm{E}$ akan mempercepat pemulihan otot supaya bugar dan kulit tetap segar

MEDIKORA Vol.IV, No 1, April 2008: 123-149 
tidak mengalami penuaan yang diakibatkan oleh radikal bebas

Kata Kunci: Masase Wajah, Vitamin E

Di era modern sekarang ini pengobatan tidak hanya penangan secara medis dan kimiawi saja tetapi pengobatan dilakukan secara alami (back to nature) untuk mengurangi efek-efek dari obat-obatan yang memiliki kandungan kimiawi tinggi. Pada atllet yang selalu mengikuti even-even kejuaran baik tingkat daerah, nasional maupun internasional, penggunaan obat-obatan harus selektif dalam memilih dan penggunaannya, karena banyak obat-obatan yang masuk dalam kriteria sebagai dopping. Sedangkan perberian obatobatan dilapangan sebagai salah satu pendukung atlet yang harus tetap bugar dan sehat dalam menjaga kondisi fisiknya. Menurut Bompa (1999) dan Sharkey (2002: 166) bahwa olahragawan/atlet setiap harinya harus selalu dituntut untuk mempunyai kondisi fisik yang prima diantaranya: menjaga kebugaran pada otot yang digunakan untuk kekuatan, kecepatan, kelincahan, koordinasi, daya ledak, kelentukan, keseimbangan, ketepatan, daya tahan dan reaksi. Sedangkan menurut Rahim (1988:30), bahwa perawatan tubuh sangat penting bagi olahragawan untuk meningkatkan penampilan dan menjaga kondisi fisik supaya tetap bugar dan sehat. 
Banyak sekali atlet yang merawat tubuhnya supaya tetap bugar selain berolahraga, seperti melakuan masase dan mengkonsumsi vitamin atau suplemen. Menurut Susi Susanti mantan srikandi pebulutangkis Indonesia yang memiliki klinik sport masase dan Spa, disebuah media televisi mengatakan bahwa atlet wanita bukan harus tampil bugar dan prima dalam bertanding untuk menang dan di kagumi permainannya oleh penonton tetapi atlet wanita harus tampil percaya diri dalam penampilan fisiknya, seperti wajah yang segar dan cantik yang selalu memancarkan inner beauty sehingga perlu perawatan khusus yaitu salah satunya dengan masase khususnya masase bagian wajah. Perawatan tubuh dan wajah tidak hanya cukup dengan masase tetapi harus menggunakan bantuan vitamin salah satunya adalah vitamin E yang bermanfaat untuk perawatan kulit, otot dan pecegahan dari radikal bebas. Sehingga sel-sel di tubuh kita akan terjaga dan tetap bugar serta sehat.

\section{MASASE}

Pada dasarnya masase (massage) telah dikenal sejak ribuan tahun yang lalu, yaitu sejak zaman pra sejarah (prehistoric times), kurang lebih 15.000 tahun sebelum masehi. Hal ini ditandai dengan temuan benda-benda

MEDIKORA Vol.IV, No 1, April 2008: 123-149 
(artifacs) oleh para arkeolog yang melukiskan penggunaan massage pada sejumlah peradaban dunia. Salah satu contoh bukti-bukti tersebut ditemukan diwilayah Eropa di dalam gua adalah berupa lukisan seorang raja, ratu dan pahlawan gladiator yang sedang mendapatkan perlakuan masase/pijatan oleh seorang wanita atau budaknya (Susan Salvo, 1999: 5). Masase berkembang dan meluas pada dunia olahraga sebagai salah satu perawatan alternatif untuk atlet yang mengalami kelelahan dan cedera ringan.

Sejarah perkembangan massage dikelompokkan ke dalam lima tahapan, yaitu: (1) Zaman Prasejarah, (2) Zaman Kuno, (3) Abad Pertengahan (4) Zaman Renaissance (5) Zaman Era Modern (Susan Salvo, 1999: 9). Sedangkan Istilah massage berasal dari bahasa Arab, yaitu dari kata mass atau mash yang berarti menekan perlahan-lahan. Sedangkan dalam bahasa Yahudi istilah massage adalah maschesch yang berarti meraba. Sedangkan dalam bahasa Indonesia, istilah masseage/masase (bahasa Indonesia yang belum dibakukan tetapi sudah dipakai) biasa diterjemahkan dengan pijat atau urut. Menurut Rahim (1988;1), masase adalah suatu perbuatan dengan tangan pada bagian-bagian yang lunak dengan prosedur manual atau mekanik yang dilaksanakan secara metodis dengan tujuan menghasilkan efek fisologis 
bagi tubuh. Sehingga teknik dan metode massage/masase memiliki bermacam-macam gerakan, sebab bentuk, struktur jaringan, dan' organ tubuh pun bermacam-macam oleh karenanya memasase harus disesuaikan.

Menurut Priyonoadi (2006:2), masase dibagi menjadi beberapa macam antara lain: sports massage, segment massage dan cosmetic massage. Sedangkan menurut Susan, (1999:9) bahwa selama lebih dari 50 tahun, beberapa gaya dan teknik massage/masase baru telah muncul. Sebagai suatu aturan umum, teknik-teknik baru ini melebihi konsepkonsep asli massage Swedia, dan sebagian besar dikembangkan di Amerika Serikat sejak 1960 seperti di bawah ini:

1. Massage Esalen (dikembangkan di Institut Esalen) di rancang untuk menciptakan suatu keadaan relaksasi yang lebih dalam dan kesehatan secara umum. Jika dibandingkan dengan system Swedia, Massage Esalen lebih lambat dan lebih berirama dan menekankan pada pribadi secara keseluruhan (pikiran dan tubuh). Banyak ahli terapi yang sebenarnya menggunakan suatu kombinasi teknik Swedia dan teknik Esalen.

2. Rolfing, dikembangkan oleh Dr. Ida Rolf, melibatkan suatu bentuk kerja jaringan dalam yang

MEDIKORA Vol.IV, No 1, April 2008: 123-149 
melepaskan/mengendurkan adhesi atau pelekatan dalam jaringan fleksibel (fascia) yang mengelilingi otot-otot kita. Secara umum, gaya ini meluruskan segmen-segmen tubuh utama melalui manipulasi pada fascia.

3. Deep Tissue Massage menggunakan stroke / tekanan yang perlahan, tekanan langsung, dan atau pergeseran. Seperti namanya, prosedur ini diaplikasikan dengan tekanan yang lebih besar and pada lapisan otot yang lebih dalam daripada massage Swedia.

3. Sport Massage adalah massage yang telah diadaptasi untuk keperluan atlit dan terdiri dari dua kategori: pemeliharaan (sebagai bagian dari aturan latihan) dan perlombaan (sebelum perlombaan ataupun setelah perlombaan). Sports massage juga digunakan untuk mempromosikan penyembuhan dari cedera.

4. Reflexology, juga dikenal sebagai terapi zona, terapi ini didasarkan pada ide oriental bahwa stimulasi dari titik-titik tertentupada tubuh mempunyai efek pada bagian-bagian lain dari tubuh. Dengan menggunakan tekanan jari dalam, ahli terapi massage mengobati area tertentu pada kaki dan tangan untuk menormalkan fungsi-fungsi dalam tubuh. Untuk pembahasan lebih lanjut, lihat bagian penjelasan yang ada pada bab refleksologi. 
5. Neuromuscular massage adalah suatu bentuk massage dalam yang mengaplikasikan tekanan jari yang terkonsentrasi pada otot-otòt tertentu. Bentuk massage ini membantu memutuskan/memecahkan siklus kejang urat dan sakit dan bentuk ini digunakan pada titik pemicu rasa sakit, yang mana merupakan simpul ketegangan dari ketegangan otot yang menyebabkan raa sakit pada bagian-bagian tubuh yang lain. Trigger point massage dan myotherapy merupakan varietas/bagian dari massage neuromuscular.

6. Bindegewebsmassage, atau connective tissue massage, dikembangkan oleh Elizabeth Dicke, merupakan suatu tipe teknik pelepasan myofascial yang terkait dengan permukaan jaringan penghubung (fascia) yang terletak diantara kulit dan otot. Para pengikut Bindegewebsmassage percaya bahwa massage pada jaringan penghubung/ikat akan mempengaruhi reflek vascular dan visceral yang berkaitan dengan sejumlah patologi dan disability/ketidak-mampuan.

Masase tidak hanya dikembangkan di Arab. Eropa, dan Amerika tetapi berkembang di Asia seperti Cina dengan accupresure dan akupuntur, di thailand dengan thai massage, di India dengan Ayuveda Massage dan di Indonesia dengan circulo massage dan frirage massage. Semua negara

MEDIKORA Vol.IV, No 1, April 2008: 123-149 
membuktikan bahwa masase sangat diperlukan untuk merawat tubuh baik dari kondisi kelelahan maupun cedera.

Massage/masase pada era modern ini, memegang peranan penting dalam mendukung prestasi atlet yang tergabung dalam rehabilitasi medik bersama medis, fisioterapi dan psikolog. Tetapi masase juga banyak sekali diminati oleh atlet wanita maupun laki-laki sebagai salah satu perawatan untuk kecantikan dan ketampanan fisik sebagai pancaran kecantikan dan ketampanan yang ada dalam dirinya.

Masase yang terkenal untuk merawat kecantikan menggunakan masase Swedia dan masase Baeuty atau masase cosmetic. Seperti yang diungkapkan oleh Susan (1999: 102), wanita perlu perawatan khusus dalam memasase wajah dan tubuh dengan sentuhan pijitan yang lembut seperti pada penatalaksaaan masase Swedia dan masase Beauty. Menurut Haryati (2005: 135-141) dan Susan (1999; 103-106), masase anggota tubuh yang utama pada wanita dilakukan pada bagian wajah. Seperti pada 8 tahap memasase wajah gambar dibawah ini: 


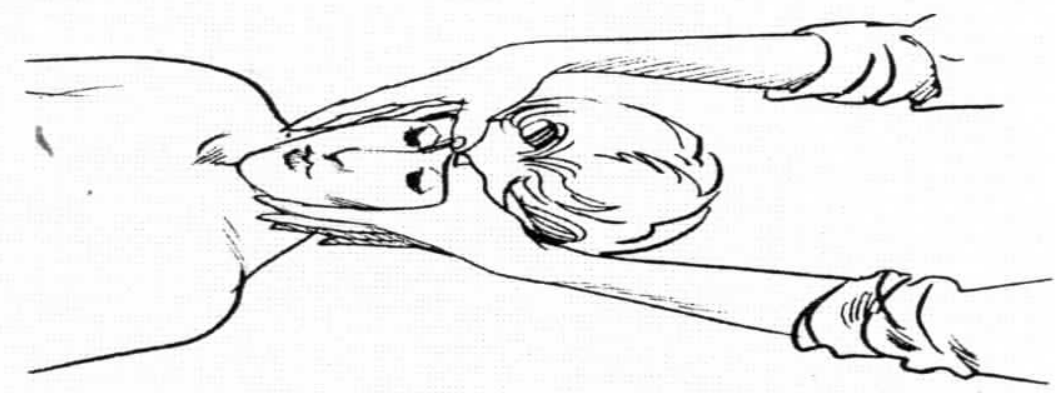

Gambar 1. Tahap 1: Memasase pada bagian dahi dengan manipulasi efflurase menggunakan kedua ibu jari menuju keatas

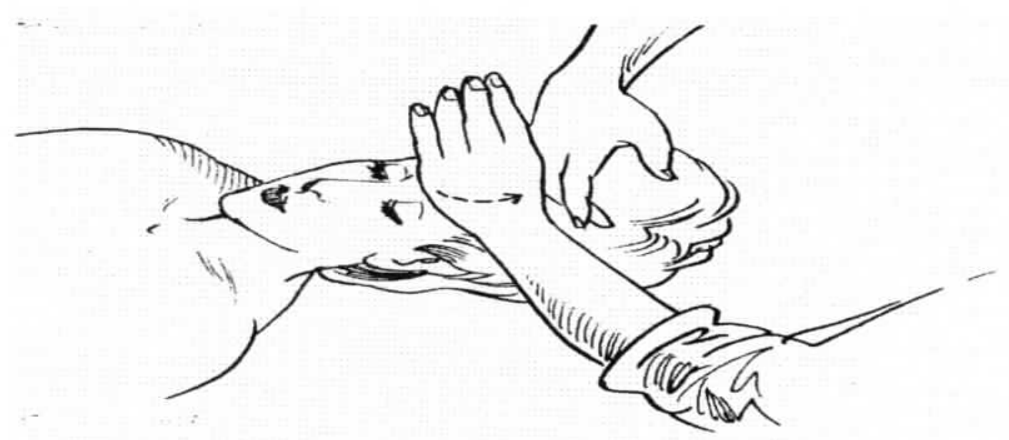

Gambar 2. Tahap 2: Memasase pada bagian dahi dengan manipulasi efflurase menggunakan kedua telapak tangan menuju ke atas 


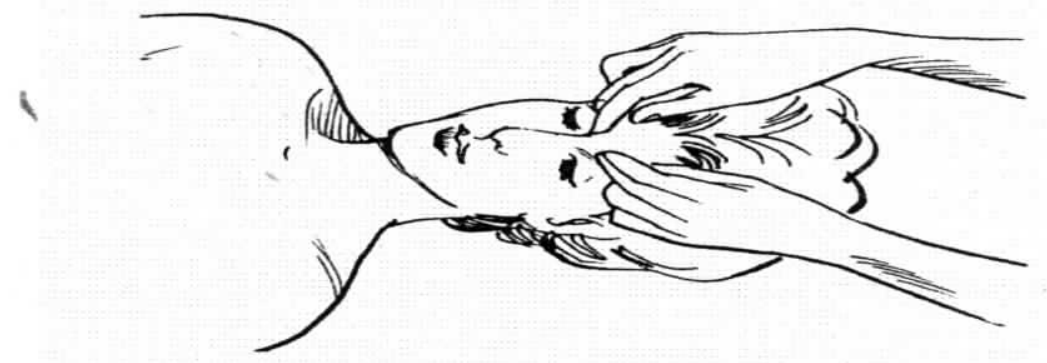

Gambar 3. Tahap 3: Memasase pada bagian dahi dengan manipulasi petrisase menggunakan kedua jari-jari tangan dibagian alis mata berjalan kearah samping

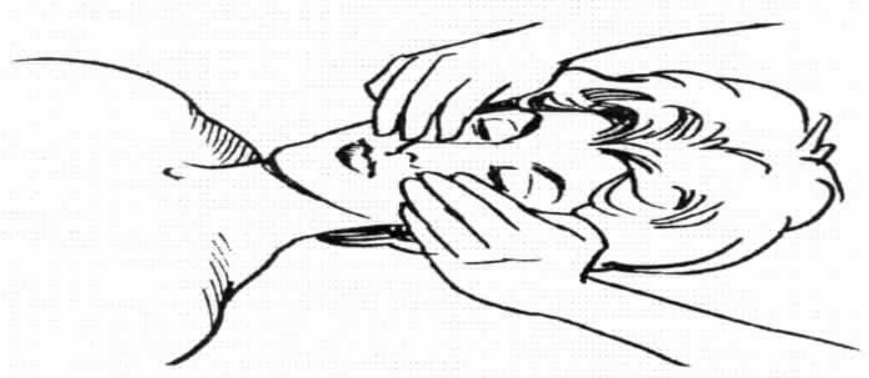

Gambar 4. Tahap 4: Memasase pada bagian pipi dengan manipulasi efflurase menggunakan kedua jari-jari tangan menuju kesamping 


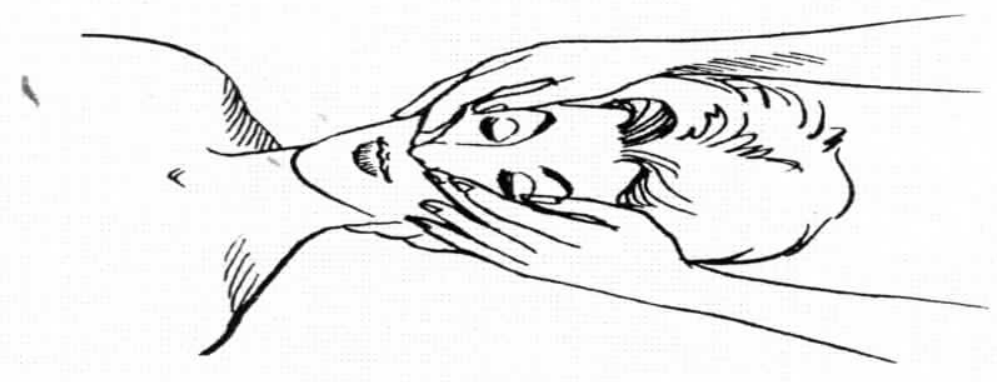

Gambar 5. Tahap 5: Memasase pada bagian pipi dengan manipulasi friction menggunakan, kedua jari-jari tangan menuju kesamping

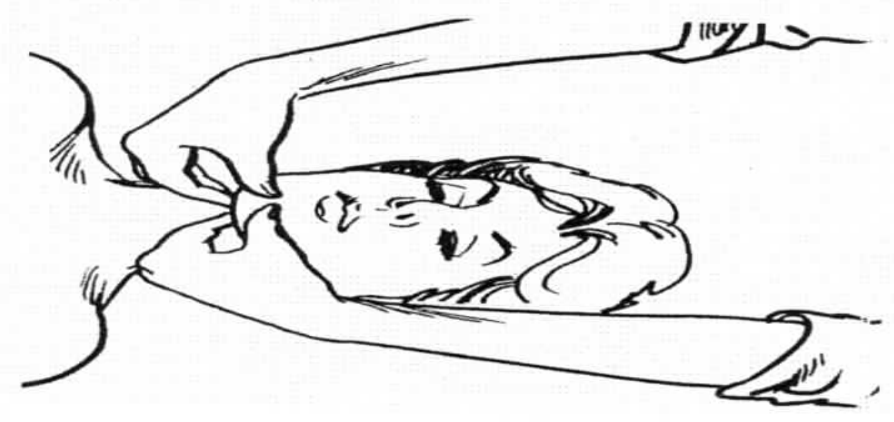

Gambar 6. Tahap 6: Memasase pada bagian dagu dengan manipulasi petrisase menggunakan kedua jari-jari tangan menuju kesamping sampai dibawah telinga

MEDIKORA Vol.IV, No 1, April 2008: 123-149 


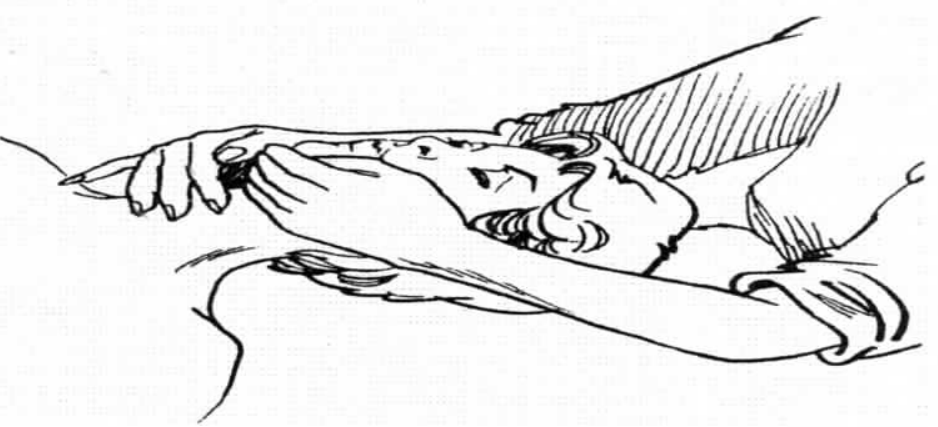

Gambar 7. Tahap 7: Memasase pada bagian dagu dengan manipulasi efflurase menggunakan telapak tangan secara bergantian menuju kesamping sampai dibawah telinga

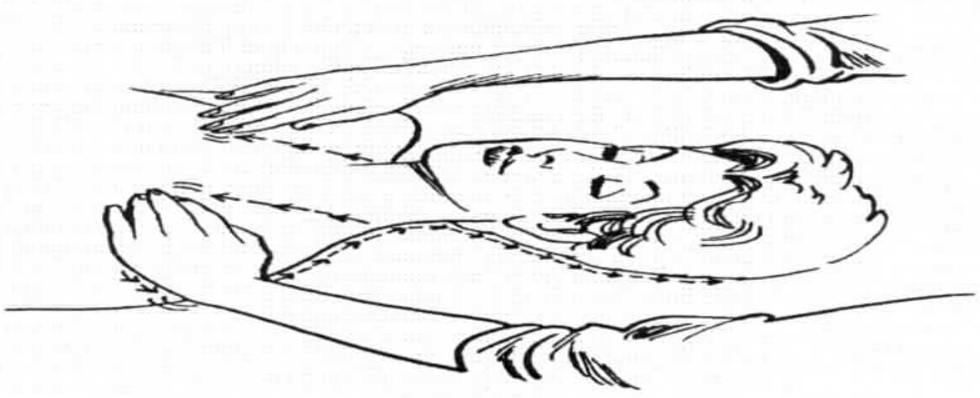

Gambar 7. Tahap 7: Memasase pada bagian leher, dada dan kepala dengan manipulasi efflurase 
menggunakan kedua telapak tangan secara bersamaan dari mulai leher, dada sampai menuju kepala

Perawatan tubuh menurut Taylor (2002;27), perawatan tubuh bisa dilakukan oleh diri kita sendiri baik dalam kondisi kelelahan maupun cedera. Begitu pula pada masase dalam perawatan tubuh dapat dilakukan oleh diri sendiri saat anggota tubuh mengalami kelelahan, otot yang kotraksi dan cedera ringan (Rahim, 1988: 7).

\section{VITAMIN E}

Olahraga dalam peradaban modern sekarang ini merupakan aktivitas fisik yang memiliki banyak manfaat terhadap kehidupan manusia, antara lain untuk kesehatan, pendidikan, rekreasi, dan prestasi. Ditinjau dari kondisi bumi pada saat ini yang mengalami pemanasan global cukup tinggi, maka manfaat olahraga bagi kehidupan manusia yang dipandang dari kesehatan akan mendapatkan pengaruh yang negatif bagi tubuh atlet itu sendiri dalam melakukan aktivitas olahraga, antara lain: pengaruh polusi udara dan sinar ultra violet yang berlebihan yang menghasilkan radikal bebas dalam tubuh. Berdasarkan penelitian Gomberg dan ilmuwan

MEDIKORA Vol.IV, No 1, April 2008: 123-149 
lainnya, istilah radikal bebas kemudian diartikan sebagai molekul yang relatif tidak stabil, mempunyai satu atau lebih elektron yang tidak berpasangan di orbit luarnya. Molekul tesebut bersifat reaktif dalam mencari pasangan elektronnya. Jika sudah terbentuk dalam tubuh maka akan terjadi reaksi berantai dan menghasilkan radikal bebas baru yang akhirnya jumlahnya terus bertambah (Rani,2006:3). Sedangkan menurut Sutanto (2006:2) mengatakan bahwa tubuh kita ini ibarat mobil. Komponen mobil yang terbuat dari logam lamakelamaan akan karatan akibat proses oksidasi. Molekul oksigen yang tidak stabil di udara itulah penyebab terjadinya proses oksidasi. Begitu juga oksigen dalam tubuh, memiliki pengaruh yang serupa. Molekul-molekul oksigen yang tidak stabil pada tubuh ini disebut sebagai radikal bebas, dimana radikal bebas ini akan menghancurkan jaringan-jaringan tubuh melalui proses oksidasi pula. Proses oksidasi ini pula yang punya andil besar dalam proses penuaan. Teori penuaan dan radikal bebas pertama kali digulirkan oleh Denham Harman dari University of Nebraska Medical Center di Omaha, AS pada 1956 yang menyatakan bahwa tubuh mengalami penuaan karena serangan oksidasi dari zat-zat perusak yang disebut radikal bebas akibat kejadian pembakaran seperti memasak, pembakaran bahan bakar 
pada mesin dan kendaraan bermotor. Paparan sinar ultraviolet yang terus-menerus, pestisida dan pencemaran lain di dalam makanan kita, bahkan karena olahraga yang berlebihan.

Pada atlet yang setiap saat melakukan aktivitas menuju ketempat latihan dan berlatih secara terus menerus dalam kondisi cuaca panas dan polusi udara tinggi akan terindikasi radikal bebas yang bisa menghacurkan jaringan-jaringan tubuh pada atlet secara tidak diduga. Sehingga bagi olahragawan atau atlet perlu penanganan khusus untuk menjaga radikal bebas tersebut. Jika tidak dikendalikan, radikal bebas dapat menyerang DNA serta merusak struktur dan fungsi membran sel, sehingga dapat memicu beberapa penyakit degeneratif (kemerosotan fungsi tubuh). hasil penelitian terakhir, aksi radikal bebas dapat dikontrol dengan sistem pertahanan antioksidan, di antaranya menggunakan vitamin $\mathrm{E}$.

Oksigen yang kita hirup akan diubah oleh sel tubuh secara konstan menjadi senyawa yang sangat reaktif, dikenal sebagai senyawa reaktif oksigen yang diterjemahkan dari reactive oxygen species (ROS), satu bentuk radikal bebas. Perisitiwa ini berlangsung saat proses sintesa energi oleh 
mitokondria atau proses detoksifikasi yang melibatkan enzim sitokrom P-450 di hati. Produksi ROS secara fisiologis ini merupakàn konsekuensi logis dalam kehidupan aerobik. Sebagian ROS berasal dari proses fisiologis (ROS endogen) dan lainnya adalah ROS eksogen, seperti berbagai polutan lingkungan (emisi kendaraan bermotor dan industri, asbes, dan lain-lain), radiasi ionisasi, infeksi bakteri, jamur dan virus, serta paparan zat kimia (termasuk obat) yang bersifat mengoksidasi. Ada berbagai jenis ROS, contohnya adalah superoksida anion, hidroksil, peroksil, hidrogen peroksida, singlet oksigen, dan lain sebagainya (Emerit, 2002). Pada Gambar 8 contoh produksi ROS pada proses sintesa energi dalam mitokondria, netralisasi oleh antioksidan enzimatis dan efeknya terhadap saraf motorik.

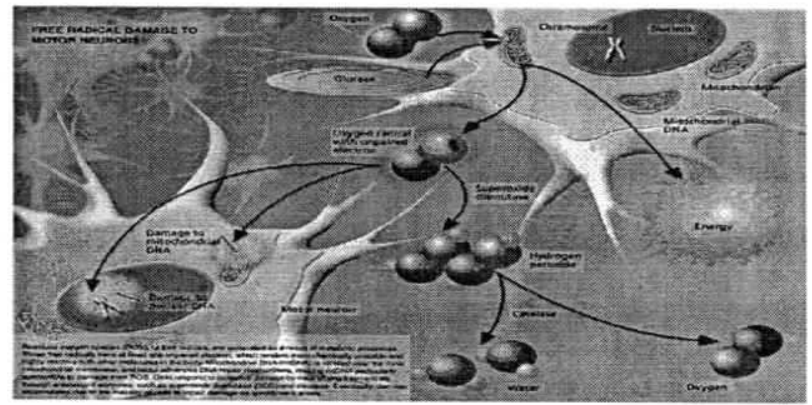

Gambar 8. Produksi ROS pada proses sintesa energi dalam mitokondria, netralisasi oleh antioksidan enzimatis \& efeknya terhadap sarafmotorik (sumber:www. als. $\mathrm{Ca} /$ ifyouhaveals/ als introduction diagnosis .aspx) 
Sebenarnya radikal bebas, termasuk ROS, penting artinya bagi kesehatan dan fungsi tubuh yang normal dalam memerangi peradangan, membunuh bakteri, dan mengendalikan tonus otot polos, pembuluh darah dan organorgan dalam tubuh kita. Namun bila dihasilkan melebihi batas kemampuan proteksi antioksidan seluler, maka dia akan menyerang sel itu sendiri. Struktur sel yang berubah turut merubah fungsinya, yang akan mengarah pada proses munculnya penyakit. Stres oksidatif (oxidative stress) adalah ketidakseimbangan antara radikal bebas (prooksidan) dan antioksidan yang dipicu oleh dua kondisi umum diantaranya: (1) kurangnya antioksidan dan (2) kelebihan produksi radikal bebas

Keadaan stress oksidatif membawa pada kerusakan oksidatif mulai dari tingkat sel, jaringan hingga ke organ tubuh, menyebabkan terjadinya percepatan proses penuaan dan munculnya penyakit. Berbagai penyakit yang telah diteliti dan diduga kuat berkaitan dengan aktivitas radikal bebas mencakup lebih dari 50, di antaranya adalah penuaan dini, stroke, asma, diabetes mellitus, berbagai penyakit radang usus, penyumbatan kronis pembuluh darah di jantung, parkinson, hingga AIDS dan lain-lain.

MEDIKORA Vol.IV, No 1, April 2008: 123-149 
Makanan yang mengandung vitamin E yang larut dalam lemak ini sebaiknya dimakan setiap hari. Termasuk di dalamnya' antara lain minyak sayuran, sayuran hijau, kacang-kacangan, kecambah, buncis, telur, hati, dan susu. Pendapat Soobrattee, dan Neergheen (2005:579), Merujuk pada RDA (Recommended Dietary Allowances), asupan vitamin $\mathrm{E}$ rata-rata sehari bagi orang dewasa pria adalah 10 $\mathrm{mg}$, dan wanita $8 \mathrm{mg}$. Diingatkan pula, vitamin $\mathrm{E}$ mudah rusak oleh panas yang tinggi dan oksidasi (terpapar oksigen). Karena itu, makanan segar, mentah, atau belum diproses merupakan sumber vitamin $\mathrm{E}$ yang terbaik. Vitamin $\mathrm{E}$ merupakan antioksidan (pencegah oksidasi) biologis yang berdiri sebagai benteng pertahanan pertama melawan peroksida lipid yang menghasilkan radikal bebas penyebab kerusakan jaringan. Senyawa yang secara kimia juga disebut tokoferol ini mempunyai kemampuan "melumpuhkan" radikal bebas (molekul reaktif, pemicu oksidasi) dan melindungi membran sel dari serangan radikal bebas. Menurut Susanto (2006: 4), mengatakan bahwa ada sembilan keampuhan vitamin $\mathrm{E}$ dalam melawan radikal bebas sepetri dibawah ini:

\section{Vitamin $\mathbf{E}$ dan polutan}

Dua polutan udara yang sangat merusak adalah ozon dan nitrogen. Ozon diproduksi dari nitrogen dioksida $\left(\mathrm{NO}_{2}\right)$, 
oksigen, dan uap gasolin tak terbakar. Sumber utama $\mathrm{NO}_{2}$ adalah proses pembakaran pada mesin mobil. Asap rokok yang tersùsun lebih dari 3.000 senyawa kimia termasuk beberapa senyawa beracun, di antaranya adalah $\mathrm{NO}_{2}$. Nitrogen dioksida dan ozon merupakan radikal bebas yang tidak stabil. Senyawa tersebut dapat merusak paru-paru dengan menyerang lemak tak jenuh dalam membran sel dan akibat yang ditimbulkan bersifat irreversible (tidak terpulihkan). Bahkan dalam tingkat yang rendah sampai 1 ppm (part per million) sekalipun.

Sistem pertahanan untuk melindungi tubuh dari radikal bebas adalah antioksidan. Suatu studi yang dilaporkan Journal of American Chemical Society (1981) menunjukkan, vitamin $\mathrm{E}$ dapat menyerap dan menetralkan radikal bebas lebih efektif daripada antioksidan lain. Selain itu dapat menurunkan bahaya serangan paru-paru serta melindungi jaringan tubuh dari polusi.

\section{Vitamin $\mathrm{E}$ dan olahraga}

Selama olahraga, tubuh mengambil dan menggunakan oksigen pada kecepatan tinggi. Latihan fisik berhubungan dengan kecepatan peroksidasi lipid. Aktivitas fisik tinggi, semisal olahragawan, disarankan untuk mengkonsumsi antioksidan primer yang lebih tinggi pula. Peran vitamin E

MEDIKORA Vol.IV, No 1, April 2008: 123-149 
dalam melawan radikal bebas yang terakumulasi selama latihan telah dibuktikan dalam studi terhadap beberapa sukarelawan. Suplementasi harian dengan 1.200 IU (International Unit) vitamin E selama dua minggu, dapat menurunkan ekskresi pentane pernapasan saat istirahat maupun selama latihan.

\section{Vitamin $\mathbf{E}$ dan penuaan}

Penelitian terhadap efek penuaan menunjukkan, radikal bebas dapat merusak sel tubuh dan menyebabkan perubahan patologis yang berhubungan dengan penuaan. Vitamin E dapat mengakhiri proses reaksi berantai radikal bebas, dengan menghambat produksi radikal bebas yang baru dan membatasi perusakan sampai batas area membran sel.

Hasil penelitian yang dipublikasikan Journal of American Dietetics Association (1978) memperlihatkan, proses di atas dapat diantisipasi dengan meningkatkan substansi pelindung termasuk antioksidan (vitamin E) yang cenderung memperlambat proses penuaan dan memperpanjang masa muda secara fisik.

\section{Vitamin $\mathrm{E}$ dan penyakit jantung}

Penyakit jantung merupakan penyebab utama kematian yang terjadi di dunia Barat. Faktor diet tertentu yang 
menyangkut kasus penyakit jantung; tingkat kolesterol yang tinggi, terutama LDL (low density lipoprotein) kolesterol, berhubungan dengan peningkatan risiko aterosklerosis.

Hasil penelitian yang dilaporkan Lancet (1991) menunjukkan, penurunan perlindungan antioksidan akan meningkatkan risiko aterosklerosis dan peningkatan asupan (intake) antioksidan akan melindungi dari penyakit jantung koroner. Sementara laporan American Journal Clinics and Nutrition (1991) berupa studi epidiomologis lintas kultural mengungkapkan, orang yang pada area geografis di mana konsentrasi vitamin E-nya dalam darah rendah mempunyai peningkatan risiko kematian karena penyakit jantung iskemik.

\section{Vitamin $\mathbf{E}$ dan saraf}

Demo terbaru menunjukkan, vitamin E mempunyai peran pokok dalam memelihara struktur dan fungsi sistem saraf manusia. Lancet melaporkan, defisiensi vitamin $\mathrm{E}$ akan mengawali dan "mengabadikan" kemerosotan perkembangan saraf otot pada anak-anak dan remaja. Akibat neurologis ini bersifat irreversible jika perlakuannya terlambat. Vitamin E dan antioksidan lain juga membantu 
mengurangi kepelikan (severity) dan gejala keterlambatan kemajuan pada penyakit saraf tertentu.

\section{Vitamin E dan katarak}

Katarak (keruhnya lensa kristal pada mata) merupakan permasalahan utama pada usia tua karena berkurangnya penglihatan sampai terjadinya buta. Lensa mata yang selalu terbuka terhadap sinar dan pembawa oksigen, sangat rentan terhadap sinar penyebab peroksidasi lemak. Proses oksidasi tersebut dipercaya merupakan hal penting dan mempercepat perkembangan katarak.

Beberapa studi menunjukkan, suplementasi vitamin $\mathrm{E}$ tidak akan melindungi katarak, tetapi keterlambatan pemberian vitamin E (defisiensi) dapat menyebabkan serangan katarak. Orang yang konsentrasi plasma darahnya tinggi akan dua atau tiga jenis antioksidan (vitamin $\mathrm{E}$, vitamin $\mathrm{C}$, dan karotenoid) mempunyai risiko terserang katarak relatif lebih rendah dibandingkan dengan orang yang konsentrasi salah satu atau lebih antioksidannya lebih rendah.

\section{Vitamin E dan kanker}

Senyawa yang termasuk golongan "antikarsinogenik" bekerja menekan kanker dengan beberapa cara, yaitu pertama menghambat inisiasi tumor dengan merubah 
fungsi sel. Kedua, "menjemput" bentuk aktif karsinogen dan mengalangi sasaran yang akan diserang. Ketiga, meningkatkan sistem pertahanan tubuh. Keempat, menghambat gerak karsinogen sebelum inisiasi kanker. Antioksidan mempunyai fungsi yang relevan dengan fungsi di atas dalam mengontrol dan mencegah kanker. Selain sebagai "pemakan" radikal bebas, vitamin E berperan meningkatkan ketahanan tubuh. Vitamin E melindungi vitamin A dari kerusakan dalam tubuh dan "menyelamatkan" selenium. Vitamin E juga berperan mencegah konversi nitrit menjadi nitrosamin (salah satu pemicu kanker) dan meningkatkan respons kekebalan. Beberapa literatur menyebutkan, antioksidan dapat menekan kanker dengan efektif, serta defisiensi senyawa ini dapat meningkatkan risiko terkena kanker tertentu.

\section{Vitamin E dan kekebalan}

Sistem pertahanan tubuh manusia dikenal sebagai substansi asing dan berperan melindungi tubuh dari serangan. Selain itu juga untuk mengenali dan merusak bentuk sel aktif pemicu kanker. Ditekankan, vitamin E merupakan rantai vital dalam fungsinya sebagai sistem kekebalan yang optimal dan meningkatkan pertahanan tubuh dari penyakit.

MEDIKORA Vol.IV, No 1, April 2008: 123-149 
Beberapa studi menunjukkan, defisiensi vitamin $\mathrm{E}$ akan menekan produksi antibodi dan merusak respons kekebalan. Vitamin E sebagai antioksidan primer berperan melindungi lemak komponen semua membran sel sebab mampu melindungi sel dari radikal bebas, juga penstabil dan pengatur membran sel untuk menjaga fungsi sel secara optimal.

Selain itu, vitamin E berperan mengatur sintesis prostaglandin (senyawa aktif yang diperoleh dari kelenjar prostat dan kandung mani), yang penting mengatur respons kekebalan.

\section{Vitamin E dan kulit}

Kulit merupakan lapisan terluar yang melindungi tubuh terutama dari radikal bebas, baik serangan fisik maupun biologis. Radikal bebas tersebut juga melibatkan sinar ultraviolet dan radiasi ionisasi pada sel epidermal. Untungnya, sel epidermis mengandung antioksidan seperti vitamin $\mathrm{E}$, ubiquinin, vitamin $\mathrm{C}$, glutation, enzim superoksidase dismutase, katalase, glutation reduktase, dan glutation peroksidase. Antioksidan tersebut mampu mengubah dan "memadamkan" potensi merusak dari radikal bebas. Seperti beberapa bahan kosmetik dilengkapi dengan vitamin $\mathrm{C}$, atau vitamin $\mathrm{E}$ untuk sabun 
kecantikan, tidak lain karena kedua vitamin tersebut mempunyai sifat antioksidan. Dengan begitu banyaknya hal yang bisa dilakukan oleh vitamin E (dan atioksidan lain) dalam menjaga kesehatan, terutama dalam melawan radikal bebas.

\section{KESIMPULAN}

Era modern sekarang ini telah merubah pandangan hidup orang banyak tentang pentingnya perawatan tubuh untuk tetap bugar dan sehat. Seperti halnya pada aktivitas atlet yang tinggi dalam berolahraga yang tidak mengenal lelah dan kondisi cuaca bagaimanapun mereka tetap berlatih. Maka atlet sangat penting dalam merawat tubuh dan menjaga kesehatan sebagai penunjang kepercayaan diri saat tampil bertanding, berpenampilan fisik yang cantik atau tampan dan terlihat inner beauty yang terpancar keluar dari dalam fisiknya.

Perawatan tubuh yang dilakukan atlet untuk terlihat cantik dan tampan serta menjaga kulit dan otot tubuh diantaranya:

1. Masase wajah, dimana masase wajah ini, sangat bermanfaat untuk merawat dan mencegah penuaan wajah

MEDIKORA Vol.IV, No 1, April 2008: 123-149 
baik kulit maupun otot wajah agar selalu tetap sehat dan bugar.

2. Vitamin E sangat bermanfaat untuk merawat otot tetap bugar dan kulit tetap segar dari dalam tubuh akibat gangguan radikal bebas

3. Penggabungan perawatan dengan masase wajah dan pemberian vitamin $\mathrm{E}$ akan mempercepat pemulihan otot supaya bugar dan kulit tetap segar tidak mengalami penuaan yang diakibatkan oleh radikal bebas.

\section{DAFTAR PUSTAKA}

Bompa, Tudor O., 1999, Power Training for Sport (Canada: Mosaic Press)

Emerit, Free Radical and Aging, Birkhauser, England.(123124), 2002

Haryati, Aroma Terapi. Gramedia. Jakarta (2005: 135-141)

M.A. Soobrattee, V.S. Neergheen, et.al, Phenolic as Potential Aantioxidant Therapeutic Agents: Mechanism and Actions, Mutation Research, 579(1-2):200-13, 2005

Priyonoadi, Bambang. "Jurnal Ilmiah Kesehatan Olahraga" Medikora Edisi 2006 
Rani Sauriasari (2006), Graduate School of Medicine, Dentistry and Pharmaceutical Sciences, Environmental Health and Preventive Medicine Laboratory, Okayama University, Jepang. Email: gms17016@cc.okayama-u.ac.jp.

Rahim. A, Sport Massage, Jakarta, 1988, h. 4

Susan. G. Salvo, Massage Therapy (Principles \& Practice), America, 1999, USA

Sharkey, Brian J, 2003, Kebugaran dan Kesehatan / Brian J.Sharkey, Penerjemah :Eri Desmarini Nasution Pt. Raja Grafindo Persada. Jakarta.

Susanto,2006. Vitamin E, Panjang Umur dan Pencegah Penyakit, Purwokerto

Soobrattee, dan Neergheen Free Radical and Food. www.als.ca/ifyouhaveals/alsintroductiondiagnosis.aspx ). journal. 2005 